\title{
Mesozooplankton in the northern Wadden Sea of Sylt: Seasonal distribution and environmental parameters
}

\author{
P. Martens
}

Biologische Anstalt Helgoland (Wattenmeerstation); D-25992 List/Sylt, Germany

\begin{abstract}
A statistical analysis was performed to determine environmental factors of significant influence on the mesozooplankton in the northern Wadden Sea of Sylt (German Bight) in 1991. The total mesozooplankton $(>76 \mu \mathrm{m})$ was significantly correlated with water temperature as was the case with the calanoid copepod Acartia sp.; Pseudo- and Paracalanus sp. were influenced by the amount of rainfall, whereas the amount of the meroplanktonic larvae of the cirripedia was related to the amount of particulate organic nitrogen in the water. A comparison of the years 1984 and 1991 demonstrates the positive effect of temperature on the copepod species Acartia sp. in summer.
\end{abstract}

\section{INTRODUCTION}

As early as 1930 , research at the Biologische Anstalt Helgoland on zooplankton in the Wadden Sea areas of Sylt focused on the relationships between environmental factors, such as temperature and salinity, and the animals. This had mainly economic reasons - the state-owned oyster banks in the research area showed decreases in catch abundance (Hagmeier \& Kändler, 1927; Hagmeier \& Schubert, 1930). Hagmeier (1940) claimed these investigations as a basis for estimations in marine production biology.

The recent research on plankton with reference to environmental factors in the northern Wadden Sea of Sylt, initiated by Hickel (1975) and Martens (1981), has taken an increasingly ecological approach which has led to the SWAP project (Sylt Wadden Sea Exchange Processes) now in progress.

The first results of comparisons of different zooplankton species from different years show interesting features with respect to their reaction to environmental factors. The examination of a single animal species shows a great variety of factors of significant influence, compared to "mass parameters" like zooplankton dry weight, for instance.

\section{MATERIAL AND METHODS}

Since 1975, various parameters were measured bi-weekly (depending on weather) at four different stations in the northern Wadden Sea of Sylt in order to study the biological oceanography of this area. This paper deals with the measurements of the following parameters taken during 1991 from the station Lister Ley (Fig. 1): 


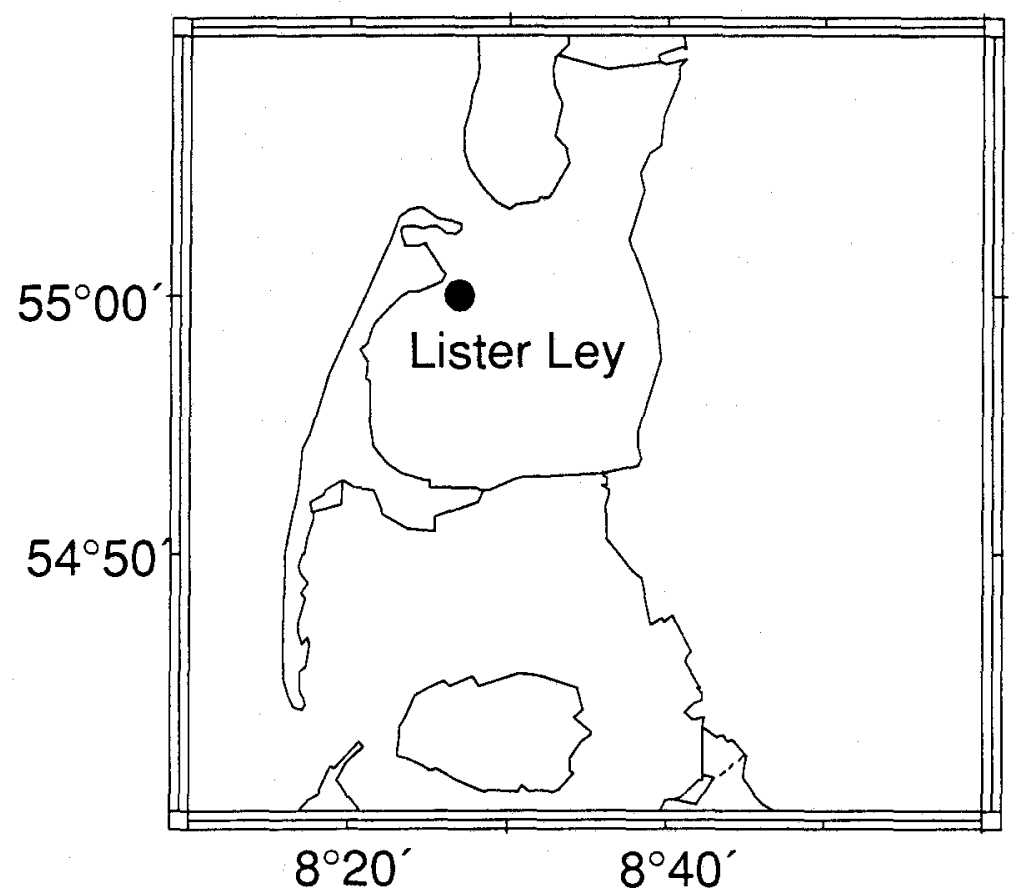

Fig. 1. Research area in the northern Wadden Sea of Sylt (German Bight, North Sea)

Water temperature

Salinity

Chlorophyll-a

Particulate organic carbon (POC)

Particulate organic nitrogen (PON)

Seston dry weight

Rainfall

\section{Mesozooplankton}

Water samples were taken with TPN-water samplers (system Hydrobios) at $1 \mathrm{~m}$ depth. Due to the high current speed at the sampling station nearly no stratification occurred. Therefore, the surface samples are taken as representative for the whole water column.

Samples for the seston dry weight determination were filtered through pre-combusted and pre-weighed Whatman GF/c glass-fibre filters, washed twice with $5 \mathrm{ml}$ distilled water to remove the salt, dried at $60^{\circ} \mathrm{C}$ for about 12 hours and weighed on a semi-micro balance (Sartorius 2474). For the determination of POC and PON, the same filters were treated afterwards with hydrochloric acid vapour for about 24 hours to remove the carbonate fraction and ashed in an elemental analyser (Carlo Erba model NA 1500). The accuracy of the method is ca $5 \%$ for POC and PON in relation to absolute values. $\left( \pm 0.05^{\circ} \mathrm{C}\right.$; reversing thermometer)

$\pm 0.001 \mathrm{~S}_{i}$ Guildline salinometer)

$\left( \pm 0.1 \mu \mathrm{g} \mathrm{dm}^{-3} ;\right.$ UNESCO standard method)

$\pm 5 \%$; Carlo Erba NA 1500 NCS-Analyser)

$\left( \pm 0.01 \mathrm{mg} \mathrm{l}^{-1}\right.$ )

( $\pm 0.1 \mathrm{dm}^{3} \mathrm{~m}^{-2} \mathrm{~d}^{-1} ;$ Deutscher Wetterdienst, Station List) 
Due to the large amount of seston in the water, no zooplankton nets could be used since the clogging factor would be too high. Samples for mesozooplankton were taken with buckets from the water surface. Thirty-five $\mathrm{dm}^{3}$ were filtered through gauze with a $76 \mu \mathrm{m}$ mesh size and the animals were preserved in $2 \%$ formaldehyde-seawater solution. The animals were counted under the microscope in the laboratory and the raw data was converted to dry weight values using empirical factors given by Hillebrandt (1972) and Martens (1975). The copepod species Pseudo- and Paracalanus are referred to as P.Calanus, since the larval stages of these species were not distinguished.

\section{STATISTICAL PROCEDURES}

The raw measuring values were transformed to weekly mean values. To determine whether parametric or nonparametric tests could be used in the statistical computations, all sets of data were tested on significant deviation from the normal distribution. If a better fit to the normal distribution could be obtained, the data were log-transformed. The methods used were Chi-square test for goodness of fit and Kolmogorov-Smirnov onesample test (StatSoft 1991). The majority of the data sets showed no significant deviation from the normal distribution; therefore, parametric methods were used. In addition, significant correlations found by these methods were confirmed by the calculation of Spearman's R, a distribution-free method. To determine parameters of significant influence on the occurrence of the zooplankton species, a stepwise variable selection was done using a backward stepwise linear regression (StatSoft 1991). In all cases, the $5 \%$ level of significance was chosen as the limit.

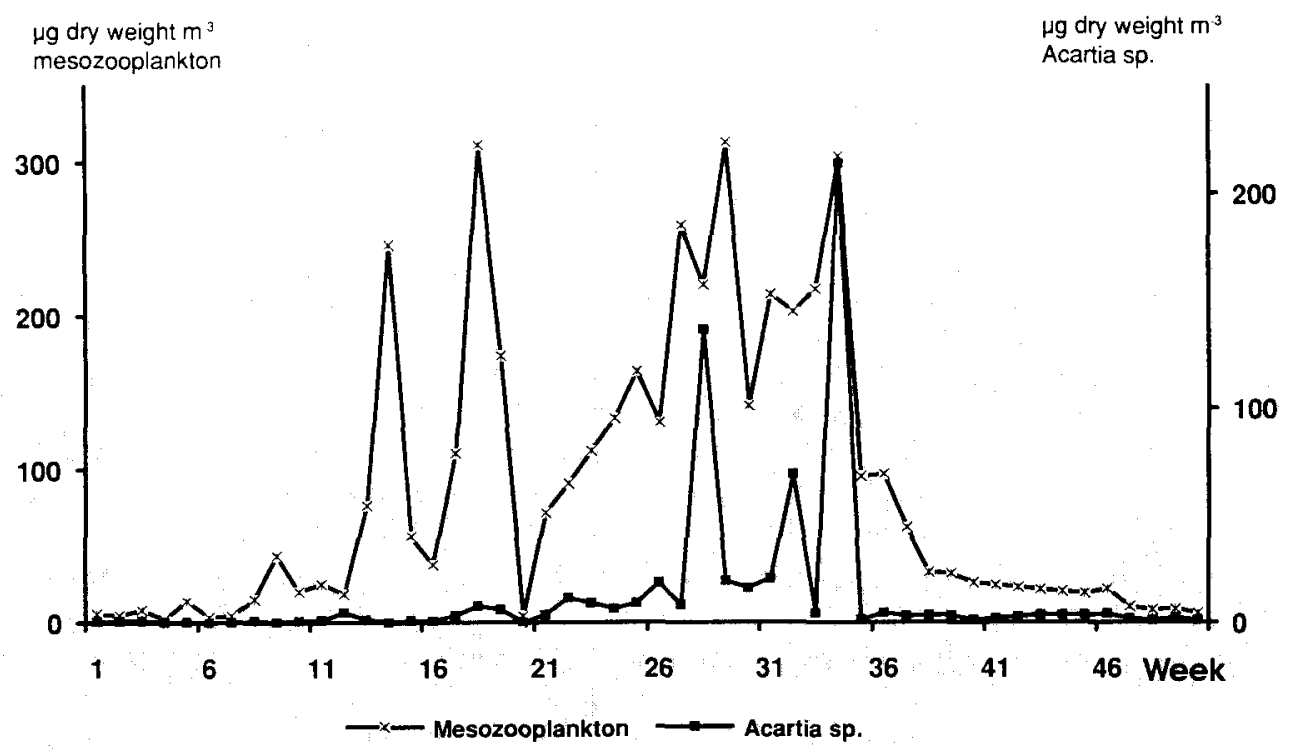

Fig. 2. Weekly mean dry weight values of mesozooplankton and Acartia sp. during 1991 in Lister Ley (northern Wadden Sea of Sylt) 


\section{RESULTS}

Figure 2 shows the seasonal distribution of the total mesozooplankton in 1991. Beginning in early spring, we have a slow increase in zooplankton starting with the meroplanktonic larvae, mainly cirripede and polychaete larvae (primarily larvae of the spionid). This occurs about the same time when the chlorophyll-a values begin to rise (around the 13th week). The meroplanktonic larvae are followed by the holoplankton, mainly calanoid copepods, P.-Calanus sp., Temora longicornis, Centropages hamatus and the dominant species Acartia sp., especially Acartia clausi.

A stepwise variable selection identifies water temperature as a parameter of significant influence on the total mesozooplankton $(R=0.744, p<0.001)$. A Spearman Rank

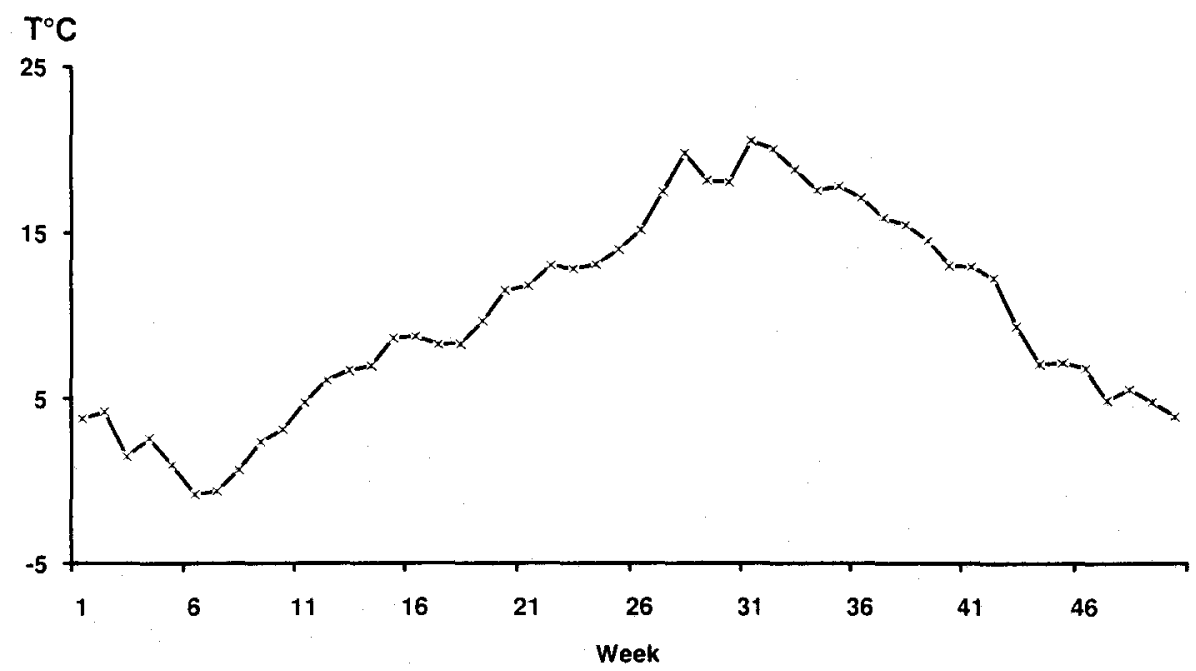

Fig. 3. Weekly mean values of water temperature during 1991 in Lister Ley (northern Wadden Sea of Sylt)

Order Correlation $(R=0.763, p<0.00001)$ demonstrates the same significant relationship between temperature and zooplankton. Figure 3 shows the water temperature in the course of the year. After a constant increase from February to June, a maximum temperature of more than $20^{\circ} \mathrm{C}$ can be found at the beginning of August, in week 32, when the maximum of copepod abundance is reached. The dominant species, Acartia sp. has its main occurrence during this time, as is shown in Figure 2. A stepwise variable selection points out that water temperature exerts a significant influence on Acartia sp. $(R=0.716, p<0.001)$. Neither salinity nor food play an important role $(p>0.2)$. A Spearman Rank Order Correlation $(R=0.762, p<0.00001)$ reveals the same significant relationship between temperature and Acartia sp. which is depicted in Figure 4 .

Figure 5 shows the seasonal distribution of the P.-Calanus species (Pseudocalanus elongatus and Paracalanus parvus). It is the first calanoid copepod in the research area during the course of the year which had a second maximum in autumn (about the 33rd week). A stepwise variable selection demonstrates that rainfall exerts a positive significant influence on plankton abundance (regression weight $B=0.361, p=0.008$ ). The 


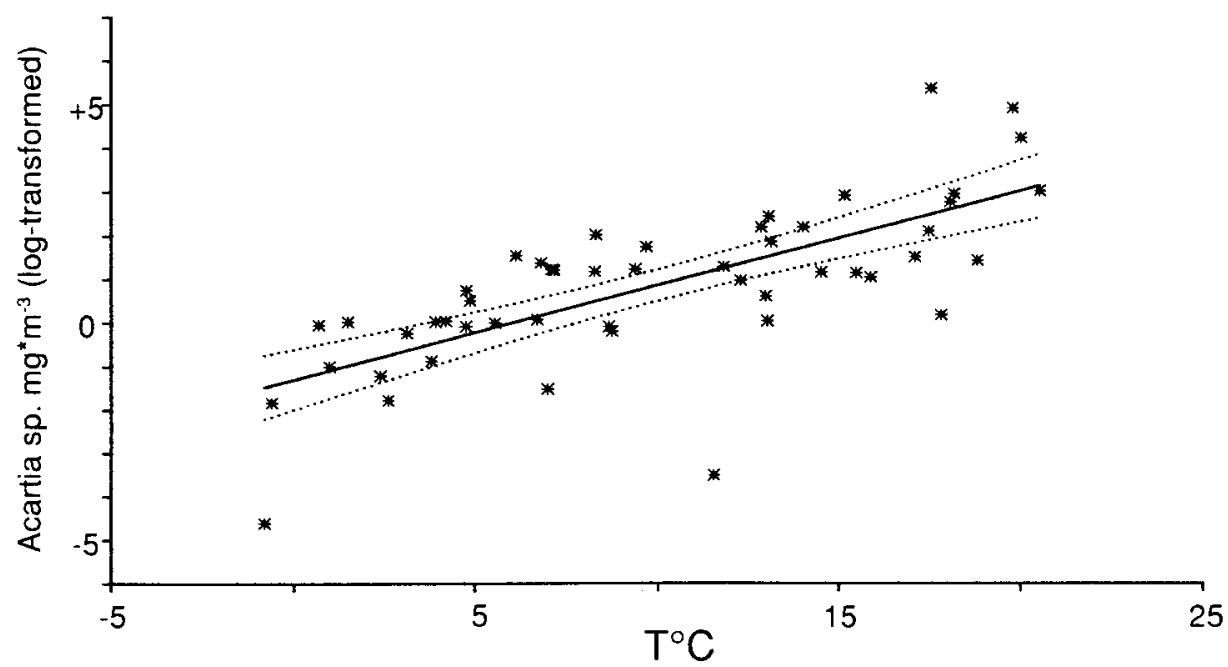

Fig. 4. Linear regression for the relation between $\mathrm{T}^{\circ} \mathrm{C}$ and Acartia sp. dry weight (log-transformed) during 1991 in Lister Ley (northern Wadden Sea of Sylt). Y-axis: $\log$ (mg dry weight $\mathrm{m}^{-3}$ );

$$
\mathrm{Y}=-1.298+0.216 \cdot \mathrm{X} ; \mathrm{R}=0.716 \text { (see Table 2); } \mathrm{p}<0.001
$$

amount of particulate organic nitrogen (PON) influences the distribution to a lesser extent, but in a negative way (regression weight $\mathrm{B}=-0.324, \mathrm{p}=0.018$ ). A Spearman Rank Order Correlation shows the influence of the parameter "rainfall" too ( $R=0.298$, $\mathrm{p}=0.036$ ) as can be seen in Figure 6. The influence of PON was not significant (confidence level $>30 \%$ ).

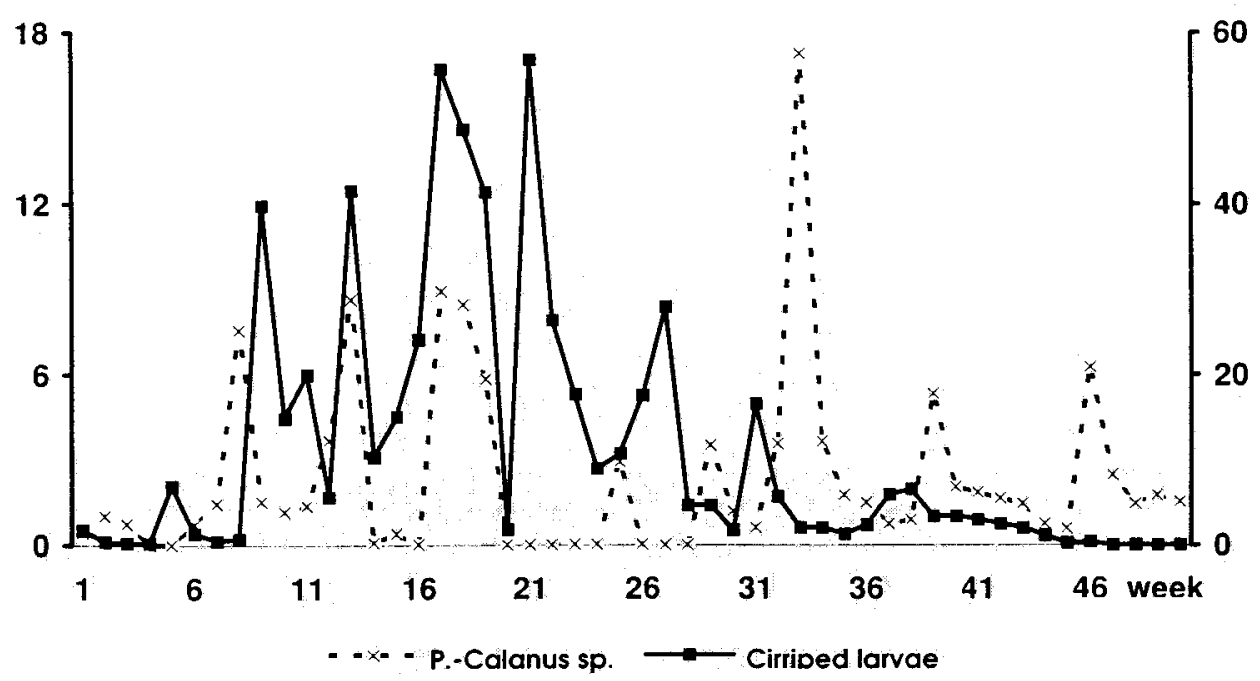

Fig. 5. Weekly mean dry weight values of $P$.-Calanus and cirripede larvae during 1991 in Lister Ley (northern Wadden Sea of Sylt) 


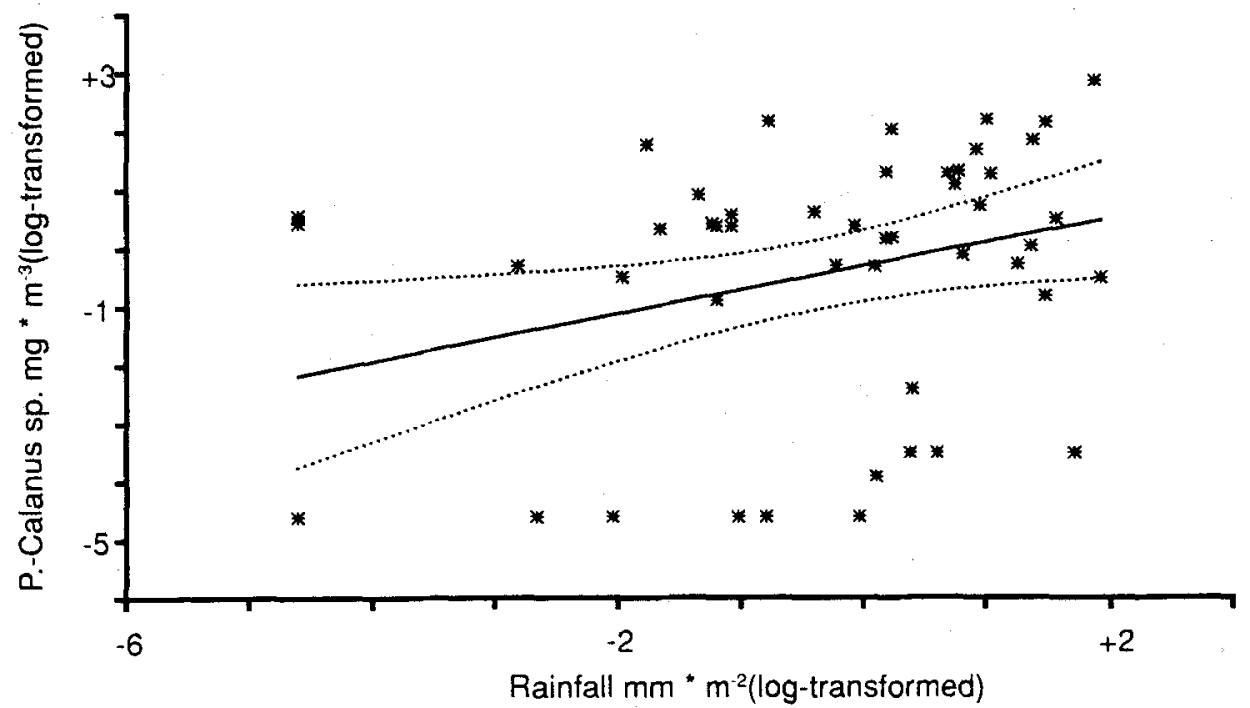

Fig. 6. Linear regression for the relation between rainfall (log transformed) and P.-Calanus-dry weight (log-transformed) during 1991 in Lister Ley (northern Wadden Sea of Sylt). Y-axis: log (mg dry weight $\left.\mathrm{m}^{-3}\right) ; \mathrm{X}$-axis: $\log \left(\mathrm{mm}\right.$ rain $\mathrm{m}^{-2}$ day $\left.^{-1}\right) ; \mathrm{Y}=-0.307+0.406 \cdot \mathrm{X} ; \mathrm{R}=0.316$ (see Table 3); $\mathrm{p}<0.008$

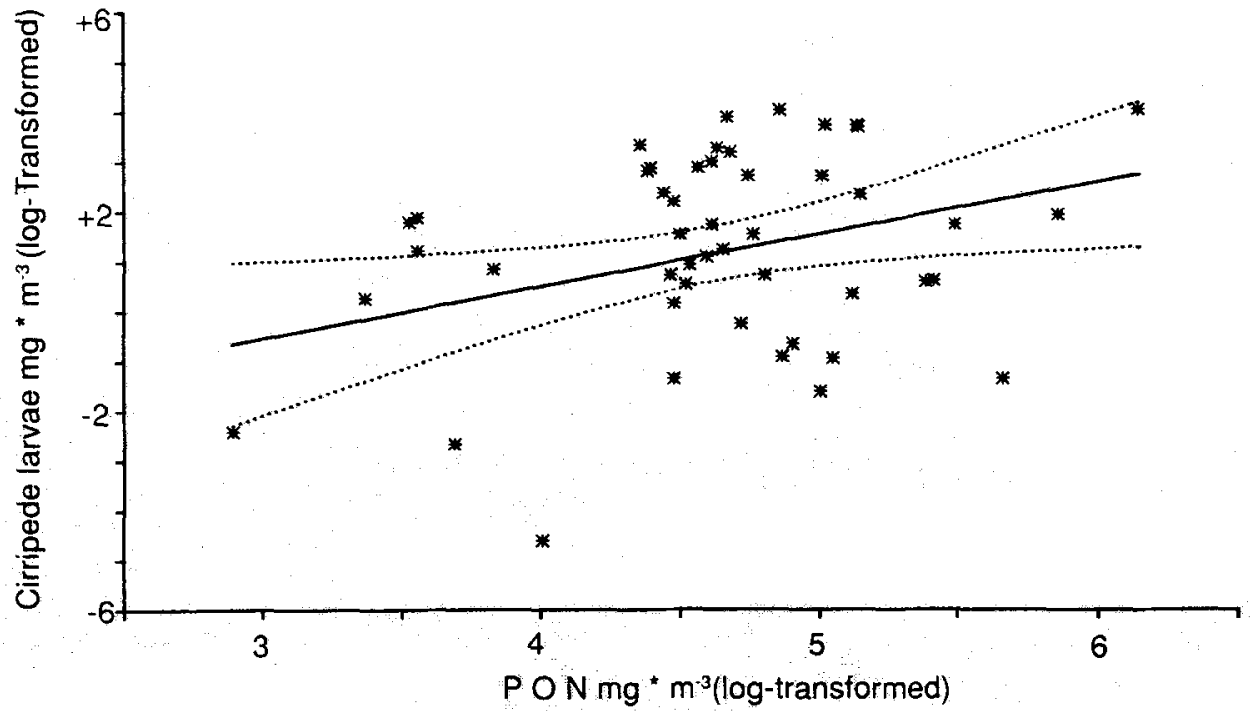

Fig. 7. Linear regression for the relation between PON (log-transformed) and cirripede larvae-dr) weight (log-transformed) during 1991 in Lister Ley (northern Wadden Sea of Sylt). Y-axis: log (mc dry weight $\mathrm{m}^{-3}$ ), X-axis: $\log \left(\mathrm{mg} \mathrm{PON} \mathrm{\textrm {m } ^ { - 3 }}\right), \mathrm{Y}=-3,674+1.044 \cdot \mathrm{X}, \mathrm{R}=0.317$ (see Table 4) 
Meroplanktonic larvae play an important role in the ecology of the Wadden Sea areas. Cirripede larvae are used as an example in Figure 5, which shows their seasonal distribution during 1991. In March one may recognize the first mass development of the cirripede larvae which can be found in great quantities up to the end of summer. A stepwise variable selection reveals that particulate organic nitrogen exhibits a highly significantly positive correlation with the occurrence of cirripede larvae (regression weight $\mathrm{B}=1.031, \mathrm{p}<0.001$ ) shown in Figure 7 ; whereas particulate organic carbon exerts a negative influence (regression weight $B=-0.859, \mathrm{p}<0.001$ ). A Spearman Rank Order Correlation shows no significant correlations between the parameters mentioned $(\mathrm{p}>0.15)$.

Two years are compared as an example for the influence of temperature on the occurrence of species. Figure 8 shows the water temperature at the time of mass occurrence of Acartia sp. The year 1991 shows higher temperatures from the beginning, with maximum values of nearly $21^{\circ} \mathrm{C}$; whereas maximal temperatures of about $19^{\circ} \mathrm{C}$ are reached in 1984 as late as the 35th week. This leads to a standing stock of Acartia sp. (mainly comprised of Acartia clausi and Acartia discaudata) which was over $400 \%$ greater in 1991 than in 1984 (Fig. 9).

\section{DISCUSSION}

The influence of water temperature on zooplankton has been previously described by various authors (Bary, 1963; Grainger \& McSween, 1976). In the German Bight and its adjacent coastal areas, temperature and salinity have been used to determine index species for different water masses (Künne, 1937). To transfer this kind of zooplankton

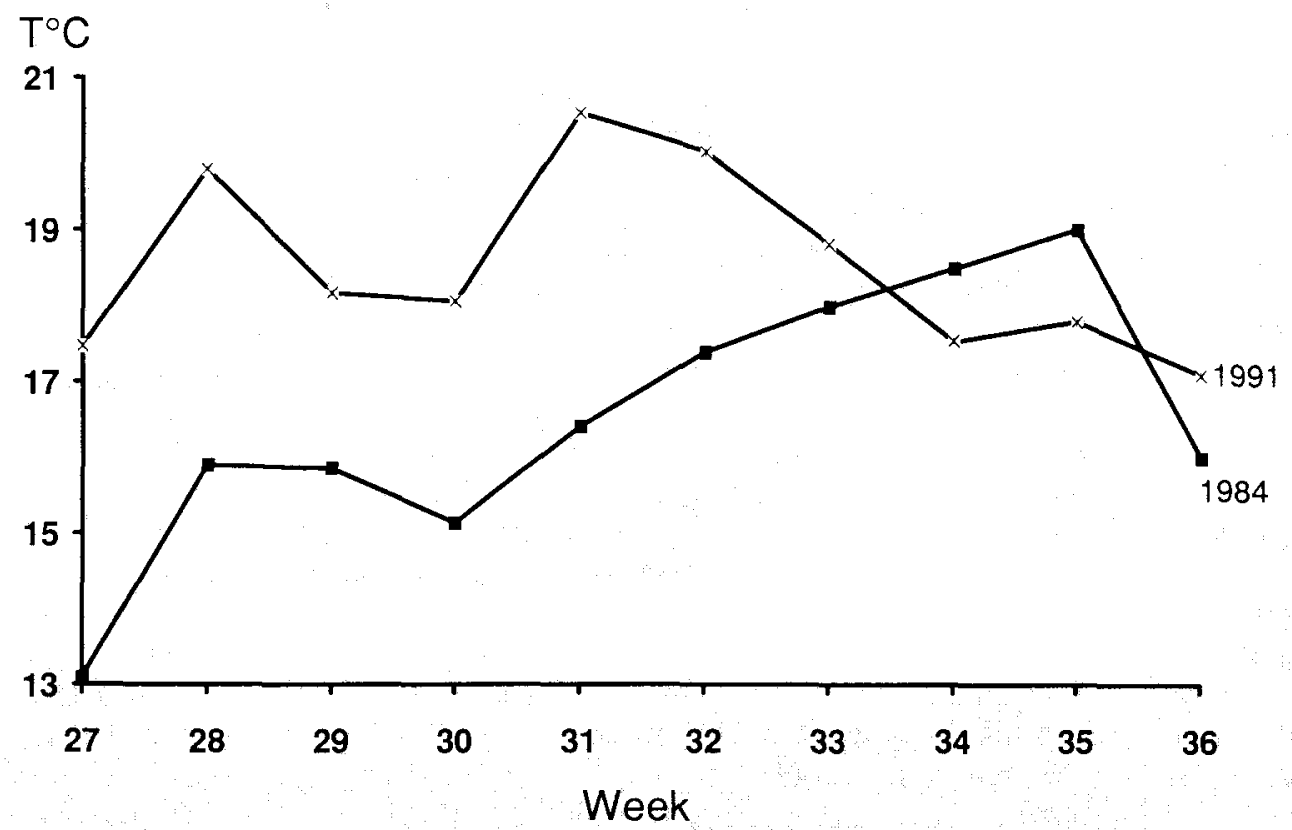

Fig. 8. Weekly mean values of water temperature during 1984 and 1991 in Lister Ley (northern Wadden Sea of Sylt); $*-*=1991 ;-1984$ 


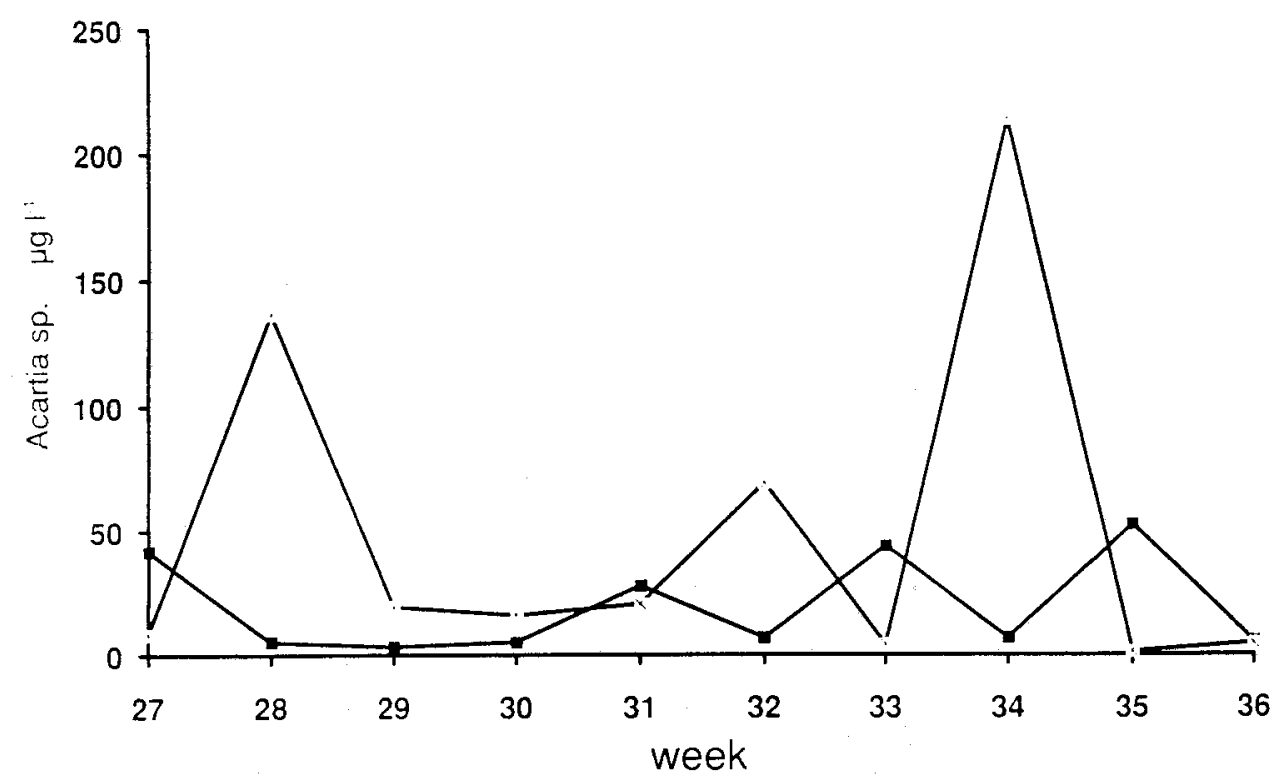

Fig. 9. Weekly mean dry weight values of Acartia sp. during 1984 and 1991 in Lister Ley (northern Wadden Sea of Sylt); X-Axis: Week; Y-Axis: Acartia sp.-dry weight; $*-*=1991$; $-\approx=1984$

research to the Wadden Sea area arouses some problems which are primarily of a technical nature. The water in the Wadden Sea area has a high load of seston particles of up to $100 \mathrm{mg} \mathrm{dm}^{-3}$ (Martens, unpubl. data). This makes the use of fine zooplankton nets nearly impossible, due to the high clogging effect. Künne (1952) avoided this problem by using very coarse nets (Helgoland larvae nets, mesh size $>500 \mu \mathrm{m}$ ). With this technique much information is lost concerning small species, especially the larval stages of the mesozooplankton. To avoid this, a bucket was used in this study, which initially might be considered a bit old-fashioned. Krsinic (1990) compared several methods for obtaining zooplankton samples in coastal areas and came to the conclusion that nets are not reliable. The optimum would be a water sampler, but samplers handling such volumes (35 litres in our case) are difficult to manipulate from small vessels. Furthermore, some of our stations in the Wadden Sea area have a water depth of less than one metre, which is too shallow to close a water sampler. Hickel (1975) obtained up to 10 times more zooplankton compared to net hauls in the research area with the same methods used during this investigation. Even relatively quick zooplankton species such as chaetognatha or copepods like Anomalocera patersonii are caught in higher numbers than with a zooplankton net. Samples during this investigation were taken only at the surface. They are thought to be representative for the whole water column. According to Hickel (1975), the strong tidal currents prevent a stratification in the tidal channels. This is confirmed by recent measurements with profiling CTD-probes which show no stable stratification in the research area (Martens, unpubl. data).

The seasonal distribution of the species studied in 1991 are very similar to findings of Hickel (1975) and Martens (1981). Both studies report the first maximum for Acartia sp. in April with a second bigger maximum in August and a smaller peak in Octohar This was 
also the case in the investigation by Hernroth \& Ackefors in the Baltic Proper (1979) and Martens' study in Kiel Bight (1976) - a strong consistency within different years and locations. Martens (1976) found the same maxima of occurrence for Pseudocalanus sp. in Kiel Bight taking place in April-June. Hickel (1975) observed the maxima in the Wadden Sea area in March--April, with a second maximum at the end of September. Künne (1952) found this species to be most abundant in the cold season. Hernroth \& Ackefors (1979) determined the broadest range of salinity tolerance to be at temperatures below $10^{\circ} \mathrm{C}$. Neither temperature nor salinity had any significant influence on Pseudocalanus sp. in this study. The factor of greatest influence was determined to be the amount of rainfall in the Wadden Sea. A direct influence of the rainfall on any single species is not very likely. Vital parameters such as salinity, temperature and food availability showed no drastic changes with the rainfall. A possible explanation for this might be provided by the prevailing wind direction. The heavy rainfalls which coincided with high occurrences of Pseudocalanus species were, in 1991, brought by southerly winds. These Pseudocalanus species might be the rest of populations from the southern German Wadden Sea areas. Krause \& Martens (1990) have shown Pseudocalanus to be relatively numerous along the south-eastern border of the North Sea down to the English Channel. Such meteorological influences on the abundance of zooplankton have been shown by Colebrook (1985) for the North Sea, where "westerly weather" had a positive influence on the zooplankton. Unfortunately, we have no quantitative data on wind speed and -direction for the whole year of 1991, so the parameter "rainfall" was taken as a measure for meteorological influences. Wind speed and -direction will be measured quantitatively in the future to ascertain these influences.

Cirripede larvae were found in this study to be positively influenced by particulate organic nitrogen. As has been shown by Barnes \& Stone (1973) and Barnes \& Barnes (1975), an increase of food availability to the adults has a positive effect on the reproduction of the animals. Barnes et al. (1978) showed a negative influence of a protein-poor diet on the cirripedes. The negative effect of particulate organic carbon, in contrast to organic nitrogen found in this study could be interpreted in the same way.

The relatively high amount of cirripede larvae in the northern Wadden Sea of Sylt (which lies within the same order of magnitude as Pseudocalanus sp.) shows the importance of meroplanktonic larvae in the coastal areas. This is confirmed by Barnes \& Barnes (1977) who gave a rough estimate of the production of cirripede larvae in the North Sea comprising 10-20\% of the whole zooplankton production.

The drastic differences found, for instance, in Acartia sp. for 1984 and 1991 illuminate the importance of long-time measurements when analysing such a complex marine ecosystem as the Wadden Sea. Pseudocalanus sp. is a good example for the necessity of measuring not only the conservative marine environmental parameters, but also of taking the meteorological influence into account.

Acknowledgements. The author is indebted to Ms. C. Reineke for technical assistance and the captain and crew of the research catamaran "Mya" of the Wadden Sea Station Sylt for excellent technical support. 


\section{LITERATURE CITED}

Barnes, H. \& Barnes, M.,1975. The general biology of Verruca stroemia (O. F. Müller). V. The effect of feeding, temperature, and light regime on breeding and moulting cycles. - J. exp. mar. Biol. Ecol. 19, 227-232.

Barnes, H. \& Barnes, M., 1977. The importance of being a "littoral" nauplius. In: Biology of benthic organisms. Ed by B. F. Keegan, P. O. Ceidigh \& P. J. S. Boaden. Pergamon Press, Oxford, 45-56.

Barnes, H. \& Stone, R. L., 1973. The general biology of Verruca stroemia (O. F. Müller). II: reproductive cycle, population structure and factors affecting release of nauplii. - J. exp. mar. Biol. Ecol. 12, 279-297.

Barnes, H., Morris, R. J \& Achituv, Y., 1978. Changes in the biochemical composition of Balanus balanoides (L.) under experimental conditions: the effect of a starch diet. - J. exp. mar. Biol. Ecol. 31, 267-281.

Bary, B. McK., 1963. Temperature, salinity and plankton in the eastern North Atlantic and coastal waters of Britain, 1957. III. The distribution of zooplankton in relation to water bodies. - J. Fish. Res. Bd Can. 20, 1519-1548.

Colebrook, J. M., 1985. Sea surface temperature and zooplankton, North Sea, 1948 to 1983. - J. Cons. perm. int. Explor. Mer 42, 179-185.

Grainger, E. H. \& McSween, S., 1976. Marine zooplankton and some physical-chemical features of James Bay related to La Grande hydro-electric development. - Tech. Rep. Fish. mar. Serv. 650, 1-91.

Hagmeier, A., 1940. Die Arbeiten der Biologischen Anstalt auf Helgoland - Ber. dt. wiss. Kommn. Meeresforsch. 9, 65-111.

Hagmeier, A. \& Kändler, R., 1927. Neue Untersuchungen im nordfriesischen Wattenmeer und auf den fiskalischen Austernbänken. - Wiss. Meeresunters. (Helgoland) 6(6), 1-89.

Hagmeier, A. \& Schubert, A., 1930. Untersuchungen über die Biologie der Auster. 4: Die Austernbrut im Wattenmeer. - Wiss. Meeresunters. (Helgoland) 18(1), 1-26.

Hernroth, L. \& Ackefors, H., 1979. The zooplankton of the Baltic Proper. - Rep. Fish. Bd Swed. 2, $1-60$.

Hickel, W., 1975. The mesozooplankton in the Wadden Sea of Sylt (North Sea). - Helgoländer Meeresunters. 27, 254-262.

Hillebrandt, M., 1972. Untersuchungen über die qualitative und quantitative Zusammensetzung des Zooplanktons in der Kieler Bucht während der Jahre 1966-1968. Diss., Univ. Kiel, 138 pp.

Krause, M. \& Martens, P., 1990. Distribution patterns of mesozooplankton biomass in the North Sea. - Helgoländer Meeresunters. 44, 295-327.

Krsinic, F., 1990. A new type of zooplankton sampler. - J. Plankton Res. 12, 337-343.

Künne, C., 1937. Über die Verbreitung der Leitformen des Großplanktons in der südlichen Nordsee im Winter. - Ber. Dt. wiss. Kommn. Meeresforsch. 8, 131-164.

Künne, C., 1952. Untersuchungen über das Großplankton in der Deutschen Bucht und im Nordsylter Wattenmeer. - Helgoländer wiss. Meeresunters, 4, 1-54.

Martens, P., 1975. Über die Qualität und Quantität der Sekundär- und Tertiärproduzenten in einem marinen Flachwasserökosystem der westlichen Ostsee. Diss., Univ. Kiel, 111 pp.

Martens, P., 1976. Die planktischen Sekundär- und Tertiärproduzenten im Flachwasserökosystem der westlichen Ostsee. - Kieler Meeresforsch. (Sonderh.) 3, 60-71.

Martens, P., 1981. On the Acartia species of the northern Wadden Sea of Sylt. - Kieler Meeresforsch. (Sonderh.) $5,153-163$.

StatSoft (Ed.), 1991. CSS: Statistica. - StatSoft Inc., Tulsa, 1-422. 